\title{
Sequence analysis and regulation of a gene encoding a cuticle-degrading serine protease from the nematophagous fungus Arthrobotrys oligospora
}

\author{
Johan Åhman, ${ }^{1}$ Bo Ek, ${ }^{2}$ Lars Rask $^{2}$ and Anders Tunlid ${ }^{1}$ \\ Author for correspondence: Johan Åhman. Tel: +46 46 2223758. Fax: + 46462224158 . \\ e-mail: Johan.Ahman@mbioekol.lu.se
}

1 Department of Microbial Ecology, Lund University, Ecology Building,

S-223 62 Lund, Sweden

2 Department of Cell Research, Swedish University of Agricultural

Sciences, Box 7055, S-750 07 Uppsala, Sweden

\begin{abstract}
The nematode trapping fungus Arthrobotrys oligospora produces an extracellular serine protease (designated PII) that immobilizes free-living nematodes in bioassays and hydrolyses proteins of the nematode cuticle. Peptides were isolated from PII and partly sequenced. Three internal peptide sequences were used to design synthetic oligonucleotides, which allowed the subsequent isolation of the gene encoding PII from a genomic library. The deduced amino acid sequence indicated that PII is synthesized as a preproenzyme containing the mature enzyme, a signal sequence and a propeptide that are removed before the enzyme is secreted into the medium. The primary sequence of PII displayed a high degree of similarity with several other serine proteases of ascomycetes belonging to the subtilisin family. Northern analysis demonstrated that PII was expressed when the fungus was starved of nitrogen and carbon and that the expression was significantly stimulated by the addition to the medium of various soluble and insoluble proteins, including fragments of nematode cuticle. The levels of the mRNA as well as the proteolytic activity of PII were repressed in the presence of more easily metabolized forms of nitrogen (including ammonia, nitrate and amino acids) or glucose. The activity of the enzyme was almost completely inhibited by the peptide Phe-Val, as well as by the amino acid Phe, without a corresponding decrease in mRNA level. Notably, peptides with similar structures are known to be secreted by the host (nematode) and to stimulate the production of infection structures (traps) of the fungus.
\end{abstract}

Keywords: Artbrobotrys oligospora, cuticle-degrading serine protease, nematophagous fungi, Northern analysis, regulation of gene expression

\section{INTRODUCTION}

Nematophagous fungi comprise a group of mainly soildwelling fungi that can infect nematodes either by forming special mycelial structures (e.g. traps) or by infecting the nematodes as spores (endoparasites). A third group of nematophagous fungi are egg parasites that can

Abbreviations: Bz-Phe-Val-Arg-NA, N-benzoyl-L-phenylalanyl-L-valyl-Larginine-4-nitroanilide; CMA, corn meal agar; LNM, low nutrient mineral salt solution; NA, 4-nitroanilide; PII, Arthrobotrys oligospora cuticledegrading serine protease.

The EMBL accession number for the nucleotide sequence of the PII gene reported in this paper is $\mathrm{X} 94121$. penetrate the eggshell and infect the eggs of root-knot and cyst nematodes. Interest in the infection biology of these fungi has increased significantly during recent years, as nematophagous fungi have been considered for use in the biological control of plant- and animal-parasitic nematodes (Kerry, 1990; Grønvold et al., 1993). The development of new methods to control such nematodes is of major importance, because the traditional methods that are based on the use of nematicides and anthelminthic drugs are no longer effective or are associated with major environmental and health concerns. To achieve successful control of parasitic nematodes using nematophagous fungi, a detailed knowledge of the infection process is needed, virulence factors have to be identified and the factors controlling their activity have to be characterized. 
The molecular background to the infection of nematodes by nematophagous fungi is, however, far from well understood. As for other parasitic and pathogenic fungi, the infection of nematodes involves a sequence of events: adhesion of the fungi to the nematode surface (cuticle), penetration of the nematode cuticle, followed by digestion and assimilation of the internal tissues of the killed nematode. By using various protease inhibitors, we have previously demonstrated that serine proteases probably play an important role during the penetration of nematodes by the nematode-trapping fungus Artbrobotrys oligospora (Tunlid \& Jansson, 1991). This is a soil-living nematophagous fungus that can grow both as a saprophyte and parasite by forming special hyphae, called traps. We have recently isolated and characterized an extracellular serine protease (PII) from $A$. oligospora that might be affected by applied serine protease inhibitors (Tunlid et al., 1994). The purified enzyme had a relatively broad substrate specificity and it was inhibited by typical serine protease inhibitors. PII is a glycoprotein with a molecular mass of approximately $35 \mathrm{kDa}$, it immobilized nematodes [Panagrellus redivivus L. (Goodey)] in bioassays and hydrolysed proteins of the purified cuticle. The $\mathrm{N}$ terminus of PII was blocked, but the sequence of one internal peptide showed a high degree of sequence similarity with a region containing the active site histidine residue of the subtilisin family of serine proteases (Tunlid et al., 1994). Subtilisin-like serine proteases have also been suggested to be involved in the penetration of the eggshell of nematodes by nematophagous fungi (Lopez-Llorca, 1990; Segers et al., 1994), and recently part of a cDNA clone for such a protease was isolated and characterized (Bonants et al., 1995).

In this study, to obtain further information on the molecular structure of PII, we have cloned and characterized the corresponding gene, PII, including the $5^{\prime}$ and $3^{\prime}$ flanking regions. Furthermore, we have examined the expression and regulation of this protease under different growth conditions.

\section{METHODS}

Peptide sequencing. PII was purified from culture filtrates of $A$. oligospora as previously described (Tunlid et al., 1994). Purified enzyme (ca. $10 \mu \mathrm{g}$ ) was digested with Acbromobacter lyticus protease (Wako Pure Chemical Industries Ltd) in $2 \mathrm{M}$ guanidine hydrochloride as described by Riviere et al. (1991), and with trypsin or staphylococcal V-8 protease in $0.2 \mathrm{M}$ $\mathrm{NH}_{4} \mathrm{HCO}_{3}$. The peptides were separated by HPLC on a Brownlee C4 Aquapore column $(2.1 \times 30 \mathrm{~mm})$ (Applied Biosystems). Pumps were System Gold (Beckman) and the detector a photo diode-array 990 (Waters, Millipore). Buffers used for reverse phase chromatography were (A) $0.1 \%(\mathrm{v} / \mathrm{v})$ trifluoroacetic acid (TFA) in $\mathrm{H}_{2} \mathrm{O}$ and (B) $0.1 \%(\mathrm{v} / \mathrm{v})$ TFA, $10 \%$ (v/v) $\mathrm{H}_{2} \mathrm{O}, 90 \%$ (v/v) acetonitrile. The gradient was $2-62 \% \mathrm{~B}$ over $60 \mathrm{~min}$ and $62-90 \% \mathrm{~B}$ over $3 \mathrm{~min}$ with a flow rate of $100 \mu \mathrm{l} \times \mathrm{min}^{-1}$. Elution was followed at $214 \mathrm{~nm}$ and fractions were collected manually. The peptides obtained were sequenced with a model $470 \mathrm{~A}$ gas-phase sequenator (Applied Biosystems) equipped with an on-line phenylthiohydantoin (PTH) amino acid analyser (model 120, Applied Biosystems) according to the manufacturer's protocol.
Isolation of A. oligospora genomic DNA. $A$. oligospora Fres. (ATCC 24927) was grown in $1 \%(\mathrm{w} / \mathrm{v}$ ) soya peptone on a rotary shaker (150 r.p.m.) at $20^{\circ} \mathrm{C}$ for $3 \mathrm{~d}$. The mycelium was filtered on a nylon mesh and high molecular mass DNA was isolated according to Wöstemeyer (1985).

Generation of a PCR probe. By aligning the obtained peptide sequences of PII with sequences of other proteases, it was possible to design three degenerate primers (oligonucleotides) for PCR amplification and hybridization: an upper (sense) primer located in the $\mathrm{N}$ terminus that included a $\mathrm{BamHI}$ site [5' AGGGATCCGAG(A)CAG(A)ACIGAC(T)A(T)G(C)IACITGGG 3', 32-fold degenerate], deduced from the amino acid sequence EQTDSTW in Peptide 1 (Table 1); a lower (antisense) primer in the $C$ terminus that included an EcoRI site [5' CTGAATTCATT(C)TTA(G)TTIGGIG(C)A(T)ICCICG(T)IATA(G)TT 3', 64-fold degenerate], deduced from the amino acid sequence NIRGSPNK in Peptide 5 (Table 1); and an internal (sense) primer over the active site histidine residue (Tunlid et al., 1994) [5' AAT(C)GGIAAT(C)GGICAT(C)GGIACICAT(C)TGT(C)GCIGGIACIATIGC 3', 32-fold degenerate], deduced from the amino acid sequence DGNGHGTHCAGTIA in Peptide 3 (Table 1). The upper and the lower primers were used for PCR amplification and the internal primer was used as a probe for Southern blot hybridizations of fragments obtained by PCR.

PCR was performed using a Boehringer Mannheim kit with genomic $A$. oligospora DNA as template. The amplification was initiated with a 3 min denaturation at $94{ }^{\circ} \mathrm{C}$ before addition of Taq polymerase, followed by 30 temperature cycles: denaturation, $94{ }^{\circ} \mathrm{C}$ for $45 \mathrm{~s}$; annealing, $42{ }^{\circ} \mathrm{C}$ for $45 \mathrm{~s}$; primer extension, $72^{\circ} \mathrm{C}$ for $45 \mathrm{~s}$. The amplification was terminated by heating at $72^{\circ} \mathrm{C}$ for $10 \mathrm{~min}$. PCR yielded three products (ca. $900 \mathrm{bp}, 1100 \mathrm{bp}$ and $1400 \mathrm{bp}$ ), as shown by gel electrophoresis in $0.8 \%(\mathrm{w} / \mathrm{v})$ agarose gel. These were further analysed by Southern blot hybridization. The filter was hybridized with the ${ }^{32} \mathrm{P}$-labelled internal primer overnight at $45^{\circ} \mathrm{C}$ and washed at moderate stringency $\left[50^{\circ} \mathrm{C}\right.$ in $6 \times \mathrm{SSC}(1 \times \mathrm{SSC}$ is $0.15 \mathrm{M}$ sodium chloride, $0.015 \mathrm{M}$ sodium citrate) and $0.1 \%(\mathrm{w} / \mathrm{v}) \mathrm{SDS}$ for $3 \times 10 \mathrm{~min}]$. The primer hybridized exclusively to the smallest PCR product (ca. $900 \mathrm{bp}$ ), which was excised from an agarose gel and cloned into a pGEM-T vector according to the manufacturer's protocol (Promega). Several positive transformants were obtained; one of these was designated pGAP. Attempts to clone the PCR fragment using the restriction enzyme sites in the primers were not successful, probably due to the presence of an internal EcoRI site in the PCR fragment. Sequencing of pGAP showed that the PCR fragment had a size of $913 \mathrm{bp}$ including the primers. That the cloned fragment encoded PII was verified by the presence of the sequences of the two primers used in the PCR amplification, the internal primer and of two other oligonucleotides deduced from peptide sequencing.

Cloning of the PII chromosomal gene. Genomic DNA from $A$. oligospora was digested with EcoRI, Bam HI, HindIII and Pst I (single or in pairs) to completion. The DNA was separated by gel electrophoresis in a $0.8 \%$ agarose gel and analysed by Southern blot hybridization. The filter was hybridized with the PCR probe of PII (a ${ }^{32} \mathrm{P}$-labelled $966 \mathrm{bp}$ ApaI-PstI insert of pGAP) overnight at $65^{\circ} \mathrm{C}$ and washed at high stringency $\left(65^{\circ} \mathrm{C}\right.$ in $2 \times$ SSC and $0.1 \%$ SDS for $3 \times 10 \mathrm{~min}$ ). In the lane with DNA digested with Bam HI and HindIII, the PCR probe hybridized to a single DNA band of approximately $3800 \mathrm{bp}$. A partial genomic library was constructed by recovering such DNA fragments from an agarose gel, followed by subcloning into pUC19. Approximately 5000 transformants were screened by colony 
Table 1. Amino acid sequences of internal peptides from PII isolated from A. oligospora

The peptides were obtained by cleavage of purified PII with trypsin, Acbromobacter lyticus protease or staphylococcal V-8 protease and separated by reverse phase HPLC. The amounts of sequenced peptides varied between 3 and 23 pmol. The peptides are numbered according to their position in the primary sequence of PII (Fig. 1). Sequences are numbered from the $\mathrm{N}$-terminal end.

\begin{tabular}{|c|c|c|c|c|c|}
\hline $\begin{array}{c}\text { Residue } \\
\text { no. }\end{array}$ & $\begin{array}{c}\text { Peptide } 1 \\
\text { (trypsin) }\end{array}$ & $\begin{array}{c}\text { Peptide } 2 \\
\text { (V-8) }\end{array}$ & $\begin{array}{l}\text { Peptide 3* } \\
\text { (Ac. lyticus) }\end{array}$ & $\begin{array}{c}\text { Peptide } 4 \\
\text { (trypsin) }\end{array}$ & $\begin{array}{c}\text { Peptide } 5 \\
\text { (V-8) }\end{array}$ \\
\hline 1 & A & $\mathrm{D}$ & $\mathrm{T}$ & $\mathrm{T}$ & $\mathrm{V}$ \\
\hline 2 & $\mathrm{E}$ & $\mathrm{Y}$ & $\mathrm{D}$ & $\mathrm{Y}$ & $\mathrm{T}$ \\
\hline 3 & $\mathrm{Q}$ & $S$ & $\mathrm{~S}$ & $\mathrm{G}$ & G \\
\hline 4 & $\mathrm{~T}$ & A & $\mathrm{D}$ & $\mathrm{V}$ & $\mathrm{N}$ \\
\hline 5 & $\mathrm{D}$ & $\mathrm{P}$ & $\mathrm{G}$ & $\mathrm{S}$ & I \\
\hline 6 & $\mathrm{~S}$ & $\mathrm{Y}$ & $\mathbf{N}$ & & $\mathbf{R}$ \\
\hline 7 & $\mathrm{~T}$ & $\mathrm{~T}$ & $\mathrm{G}$ & & G \\
\hline 8 & W & & $\mathrm{H}$ & & $\mathrm{S}$ \\
\hline 9 & $\mathrm{G}$ & & $\mathrm{G}$ & & $\mathrm{P}$ \\
\hline 10 & $\mathrm{~L}$ & & $\mathrm{~T}$ & & $\mathbf{N}$ \\
\hline 11 & & & $\mathrm{H}$ & & $\mathrm{K}$ \\
\hline 12 & & & $\mathrm{C}$ & & I \\
\hline 13 & & & $\mathrm{~A}$ & & \\
\hline 14 & & & $\mathrm{G}$ & & \\
\hline 15 & & & $\mathrm{~T}$ & & \\
\hline 16 & & & I & & \\
\hline 17 & & & $\mathrm{~A}$ & & \\
\hline
\end{tabular}

* This sequence has been published by Tunlid et al. (1994) as TNSNGN... However, further examination of the HPLC chromatograms showed that the peptide should be TDSDGN...

blot hybridization. The filters were hybridized with the PCR probe overnight at $65^{\circ} \mathrm{C}$ and washed at high stringency $\left[65^{\circ} \mathrm{C}\right.$ in $1 \times \operatorname{SSPE}\left(0.18 \mathrm{M} \mathrm{NaCl}, 10 \mathrm{mM} \mathrm{NaH}_{2} \mathrm{PO}_{4}, 1 \mathrm{mM}\right.$ EDTA, $\mathrm{pH} 7 \cdot 7$ ) and $0.1 \%$ SDS for $3 \times 10 \mathrm{~min}]$. Several positive Escherichia coli clones containing plasmids with the expected $3.8 \mathrm{~kb} \mathrm{BamHI-HindIII}$ fragment were isolated. One of these clones was designated pUBH and subsequently sequenced.

To search for sequences similar to $P I I$ in the genome, a filter containing genomic DNA digested with EcoRI, EcoRV, BamHI or HindIII was analysed by Southern blot hybridization. The filter was hybridized with the ${ }^{32}$ P-labelled PCR probe of PII overnight at $55^{\circ} \mathrm{C}$ and subsequently washed at several different levels of stringency (from $55-65^{\circ} \mathrm{C}$ in 2 or $6 \times$ SSC).

Sequence analysis. DNA sequencing was performed on both single- and double-stranded pGAP and on double-stranded pUBH templates using the dideoxy chain-termination method (Sanger et al., 1977) (2.0 DNA Sequenase Kit, USB) or fluorescence-based dideoxy sequencing using a PRISM Ready Reaction DyeDeoxy Terminator Cycle Sequencing Kit from Perkin Elmer Cetus Instruments according to the manufacturers' protocol. In the pGAP clone, both strands of the insert were sequenced. In the $\mathrm{pUBH}$ clone, $2487 \mathrm{bp}$ were sequenced, starting from the $5^{\prime}$ end of the insert. Both strands were sequenced over the coding and the adjacent $5^{\prime}$ and $3^{\prime}$ regions (corresponding to positions 487-2337, numbered from the $5^{\prime}$ end of the insert). Analysis of the DNA sequence was performed using the GCG software package (Genetics Computer Group, version 8.1, Madison, WI, USA). Nucleotide and amino acid sequences were compared with sequences in the EMBL and Swiss-Prot data libraries using the GCG programs FASTN and FASTP (Lipman \& Pearson, 1985). Pairwise and multiple alignments (including cluster analysis) of sequences were made using the GCG programs BESTFIT and PILEUP, respectively. The sequences were also analysed by PHYLIP (Phylogeny Inference Package) version 3.5c (Felsenstein, 1989).

Growth experiments. Induction and regulation of PII by various carbon and nitrogen sources were examined in a series of experiments using liquid cultures of $A$. oligospora. The fungus was maintained on corn meal agar (CMA) (Difco) supplemented with $2 \mathrm{~g} \mathrm{KH}_{2} \mathrm{HPO}_{4} \mathrm{l}^{-1}$. The liquid medium contained a modified low nutrient mineral salt solution (LNM) (NordbringHertz, 1973) containing $\left(1^{-1}\right): 0.2 \mathrm{~g} \mathrm{MgSO}_{4} .7 \mathrm{H}_{2} \mathrm{O}, 0.003 \mathrm{~g}$ $\mathrm{FeCl}_{3} \cdot 6 \mathrm{H}_{2} \mathrm{O}, 0.88 \mathrm{~g} \mathrm{ZnSO}_{4} \cdot 7 \mathrm{H}_{2} \mathrm{O}, 0 \cdot 40 \mathrm{~g} \mathrm{MnSO}_{4} .4 \mathrm{H}_{2} \mathrm{O}, 5 \mu \mathrm{g}$ biotin, $200 \mu \mathrm{g}$ thiamin, $1.0 \mathrm{~g} \mathrm{KCl}$ and $1.0 \mathrm{~g} \mathrm{~K}_{2} \mathrm{HPO}_{4}$, with $\mathrm{pH}$ adjusted to $6 \cdot 4$. To establish a nitrogen-starved mycelium of $A$. oligospora, $50 \mathrm{ml} \mathrm{LNM}$ supplemented with $\left(1^{-1}\right) 10 \mathrm{~g} \mathrm{D}$-glucose and $0.002 \mathrm{~g} \mathrm{NaNO}_{3}$, was inoculated with a water suspension of conidia prepared from a 2 - to 3 -week-old culture growing on CMA and incubated on a rotary shaker $\left(120\right.$ r.p.m.) at $20^{\circ} \mathrm{C}$ for $2 \mathrm{~d}$. The mycelium was filtered on a nylon mesh, washed with sterile $\mathrm{LNM}$ and transferred to $50 \mathrm{ml} \mathrm{LNM}$ containing various carbon and nitrogen sources. The mycelium was incubated for a further period of $0-24 \mathrm{~h}$ under the same conditions as above. The cultures were harvested by filtration; the filtrates were used for protease assays and the mycelia were either extracted for RNA, as described below, or used for dry weight measurements. The $\mathrm{pH}$ of the growth media at the end of the incubations was between 5.6 and 6.4 .

The following protein substrates were used: albumin fraction $\mathrm{V}$ (Boehringer Mannheim), collagen (Sigma, type I insoluble) and gelatin (Sigma). Polyamino acids, peptides and amino acids 
were from Sigma. Fragments of cuticle were prepared from the nematode $P$. redivivus by sonication and treatment with $1 \%$ SDS according to Cox et al. (1981). Before being used in the assays, the fragments were extensively washed with water and lyophilized. Soluble proteins, peptides and amino acids were sterilized by filtration $(0.22 \mu \mathrm{m}$ pore size), and collagen and cuticle fragments were autoclaved. Proteins and amino acids were added at a concentration of $1 \mathrm{mg} \mathrm{ml}^{-1}$, and polyamino acids at $0.5 \mathrm{mg} \mathrm{ml}^{-1}$, unless otherwise stated. The viability of the fungus after treating the mycelium with the various polyamino acids was evaluated by transferring the mycelium incubated with the polyamino acids to an agar plate containing CMA. The fungi were incubated and the radial growth of the mycelia was observed after $1-3 \mathrm{~d}$.

Protease assays and Northern blot analysis. The hydrolytic activity of PII was measured by using the peptide substrate $N$ benzoyl-L-phenylalanyl-L-valyl-L-arginine-4-nitroanilide $(\mathrm{Bz}$ Phe-Val-Arg-NA) as described previously (Tunlid et al., 1994). The proteolytic activities are given in pmol 4-nitroanilide (NA) liberated $\mathrm{ml}^{-1} \mathrm{~min}^{-1}$. RNA was isolated from the mycelia using acid guanidinium thiocyanate/phenol/chloroform (Chomzcynski \& Sacchi, 1987). To normalize the amount of RNA used for the Northern blots, samples of the extracted RNA were initially analysed by denatured formaldehyde agarose $(1 \%)$ electophoresis and stained with ethidium bromide (Sambrook et al., 1989). The amount of RNA was evaluated by estimating the intensity of the $28 \mathrm{~S}$ and $18 \mathrm{~S}$ rRNA bands in an ultraviolet transilluminator. The electrophoresis experiments were repeated with approximately equal amounts of RNA and transferred to a Hybond-N+ membrane (Amersham). The filters were hybridized at $65^{\circ} \mathrm{C}$ in $6 \times$ SSC overnight with a ${ }^{32} \mathrm{P}$ labelled DNA fragment of PII (a $1371 \mathrm{bp} B g / \mathrm{II}$ insert of $\mathrm{pUBH}$ containing a major part of the ORF). The filters were washed at $65^{\circ} \mathrm{C}$ in $6 \times$ SSC and $0.1 \%$ SDS before being autoradiographed. As a control for equal loading, the filters were also hybridized with a $18 \mathrm{~S}$ rRNA probe obtained from Vicia faba (Yakura et al., 1984).

Other methods. Hybond-N+ and Hybond-N filters (Amersham) were used for DNA blotting and for colony blotting, respectively, according to the manufacturer's manual. Oligonucleotides were end-labelled with $\left[\gamma^{32} \mathrm{P}\right] \mathrm{dATP}[>5000 \mathrm{Ci}$ $\left.\mathrm{mmol}^{-1}\left(185 \mathrm{TBq} \mathrm{mmol}^{-1}\right)\right]$ using polynucleotide kinase (Sambrook et al., 1989). Double-stranded DNA fragments were labelled with $\left[\alpha-{ }^{32} \mathrm{P}\right] \mathrm{dCTP} \quad\left[\approx 3000 \mathrm{Ci} \mathrm{mmol}^{-1}(111 \mathrm{TBq}\right.$ $\mathrm{mmol}^{-1}$ )] using the random-primed DNA method (Rediprime DNA labelling system, Amersham). Large-scale plasmid DNA preparation was done with Wizard maxipreps and small-scale DNA preparations with Wizard minipreps as described by the manufacturer (Promega). Restriction endonucleases, Taq DNA polymerase, T4-DNA ligase and other enzymes were purchased from Boehringer Mannheim unless otherwise stated and were used according to the instructions of the supplier.

\section{RESULTS}

\section{Cloning of PII}

After digestion of PII with various proteases, five internal peptides were isolated and sequenced (Table 1). Sequences from three of these peptides were used to design oligonucleotide primers for subsequent PCR amplification (Peptides 1 and 5) and hybridization (Peptide 3). The obtained PCR fragment (913 bp) of PII was used as a probe to isolate the entire PII gene from genomic DNA. The isolated genomic clone ( $\mathrm{pUBH})$ was shown to encode
-244 gcastccggatgggatcttgcacagtatccctacgatgttctcatcatcgacctttgatt -184 aatctagatgtcgacagtagagacatt t t tctataneaagctct tgcgccetcgata 124 gaatcaaatecactceatcatcagcagcagtct tgaaagcaatcatcttcagacctatag -64 agtttcatcttectcctagtatctctcgatctacagtacacttecataaattcaaatc $\begin{array}{lllllllllllllllllllllllllllll}M & L & T & N & G & L & I & S & L & L & A & I & A & G & L & A & T & N & A\end{array}$ -4 CaCAATGCTTACGAACGGCCTCATCTCCCTTCTAGCAATCGCTGGCTTGGCTACCAATGC

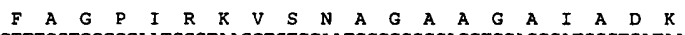
Y I V V L $R$ K G L S D S A $V$ Q T Y H R I

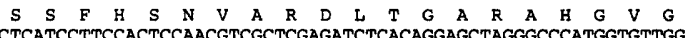
176 CTCATCCTHCCACTCCAACGTCGCTCGAC

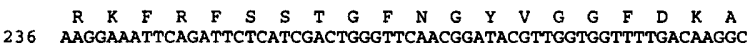
$296 \underset{\text { AACTCTCCAGGAGATCTTGAACTCTCCTGAGGTCGACTACGTTGAACAAGACACCGTTGT }}{\text { T }}$

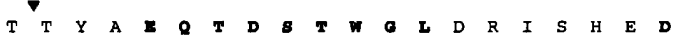
356 TACTACGTACGCTGAACAGACTGACTCCACCTGGGGCCTCGACCGTATCTCCCATGAGGA $\begin{array}{llllllllllllllllllll}\mathbf{Y} & \mathbf{8} & \mathbf{A} & \mathbf{P} & \mathbf{Y} & \mathbf{T} & \mathbf{Y} & \mathrm{E} & \mathbf{Y} & \mathrm{D} & \mathbf{E} & \mathbf{T} & \text { A } & \text { A } & G & \text { A } & G & \text { T } & \text { T } & V\end{array}$

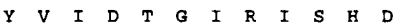

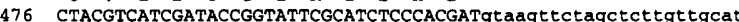
$\begin{array}{lllllllll}E & F & T & V & N & G & S\end{array}$ 536 tgaatatatcatctatcagttgtctaataatattatagGAATTCCAAACCGTGAATGGTT

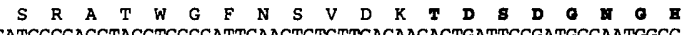
596 CATCCCGAGCTACCTGGGGATTCAACTCTGTTGACAAGACTGATTCCGATGGCAATGGCC 656 ACGGTACCCACTGCGCTGGTACTATCGCTGGAAAGACCTATGGTGTCTCCAAGAAGGCCA $\underset{\text { AGGTTGTCGCTGTTAAGGTTCTTAGCGCTGGTGGTTCCGGTTCTACCGCTGGCGTCGTCT }}{V}$ $\begin{array}{llllllllllllllllllll}G & M & N & W & V & A & E & N & A & T & P & N & F & S & V & A & S & M & S & L\end{array}$ 776 CTGGAATGAACTGGTA $836 \underset{\text { TGGGAGGTTCCAAATCTGCCGCCCTCAATACTGCCGTTGACGCTATCTTCAATGCCGGAA }}{\mathbf{G}}$ $\begin{array}{llllllllllllllllllll}T & I & V & V & A & A & G & N & E & N & Q & D & A & K & N & V & S & P & A & S\end{array}$ 896 TCACCATCGTTGTCGCTGCCGGTAACGAGAACCAGGATGCTAAGAACGTTTCACCCGCCT

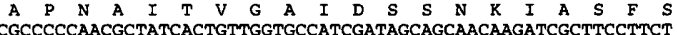
1016 CTAACTGGGGACTCTCATCGATGTCTTCGCTCCAGGTGTTGGTGTCTTGAGCTCTTGGG

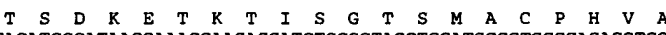
1076 CTACATCCGATAAGGAAACCAAGACCATCTCCGTACCTCCATGGCCTGCCCACACGTCG

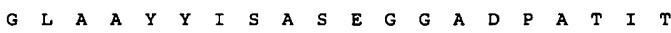
1136 CTGGCTTGGCCGCTTACTACATCAGCGCTTCCGAGGGTGGTGCCGATCCAGCAACCATCA $D K$ I $T S S$ CCGATAAGATCACCAGCAGCGCCGTCAGTGGT

Fig. 1. Part of the nucleotide sequence of the pUBH clone encoding $P I I$ with the $5^{\prime}$ and $3^{\prime}$ flanking regions isolated from A. oligospora. Coding nucleotides are in upper case letters. The numbering of nucleotides (left margin) starts at the predicted translational initiation ATG codon (the A in ATG being +1 ). The predicted amino acid sequence is from the first methionine and numbered along the right margin. A putative CAAT-box, TATA-box and a cap-site are in bold. Polypeptides obtained by peptide sequencing are in bold. Nucleotide sequences used in PCR primers and hybridization probes are underlined. The suggested processing sites for cleavage of the signal peptide and proregion are denoted by $\boldsymbol{\nabla}$ and the proposed stop codon is denoted by $* \star \star$.

PII by the identification of an ORF containing the deduced sequences of the five internal peptides (Fig. 1).

Southern blot analysis of genomic DNA of $A$. oligospora showed that during hybridization under a high level of stringency (filter-washed at $65^{\circ} \mathrm{C}$ in $2 \times \mathrm{SSC}$ and $0.1 \%$ SDS) the PCR gene fragment hybridized to single bands in lanes with DNA digested with restriction enzymes having no internal recognition site in the cloned gene (Bam HI, EcoRV and HindIII) and to two bands in DNA 


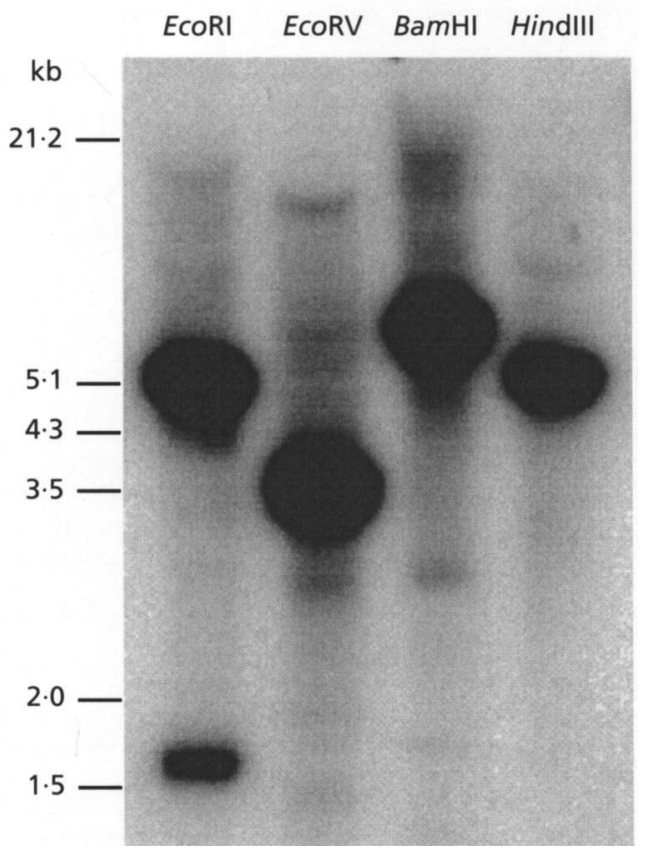

Fig. 2. Hybridization of genomic DNA from $A$. oligospora with the PCR probe of PII (a ${ }^{32}$ p-labelled 966 bp Apal-Pstl insert of pGAP). DNA isolated from mycelium was digested with EcoRI, EcoRV, BamHI or HindIII and separated by gel electrophoresis in a $0.8 \%$ agarose gel. After transfer to a nylon membrane, the blot was washed at moderate stringency $\left(55^{\circ} \mathrm{C}\right.$ in $6 \times \mathrm{SSC}$ and $0.1 \%$ SDS) and autoradiographed.

digested with EcoRI which has one internal recognition site in PII (at position 574 in Fig. 1). However, during hybridization under moderate stringency (filter-washed at $55^{\circ} \mathrm{C}$ in $6 \times \mathrm{SSC}$ ) several minor bands appeared (Fig. 2). These results indicate that there is probably only one gene encoding PII in the genome, but that related gene(s) having some similarity to $P I I$ can be found in the genome of $A$. oligospora.

\section{Nucleotide sequence}

The isolated clone pUBH contained the entire nucleotide sequence encoding PII as well as the $5^{\prime}$ and $3^{\prime}$ flanking regions (Fig. 1). The identified ORF begins with a translation initiation site (ATG) codon and ends at a translation termination codon (TAA) separated by $1284 \mathrm{bp}$. The sequence immediately preceding the ATG codon fits the consensus sequences of the eukaryotic translation initiation site with a CACA at position -4 to -1 (the A in ATG being +1). Several other sequences that are homologous to eukaryotic promoter elements can be identified further upstream from the ATG start codon . At $-152 \mathrm{bp}$, the sequence TATAAA indicates a potential TATA-box and a putative CAAT-box can be identified at -243 bp (Gurr et al., 1987). A putative capsite with the sequence TCCACTCC, which is similar to the consensus cap-site sequence YYCAYYYYY (where $\mathrm{Y}=$ pyrimidine) (Corden et al., 1980), can be identified $36 \mathrm{bp}$ downstream from the TATA-box. The ORF is

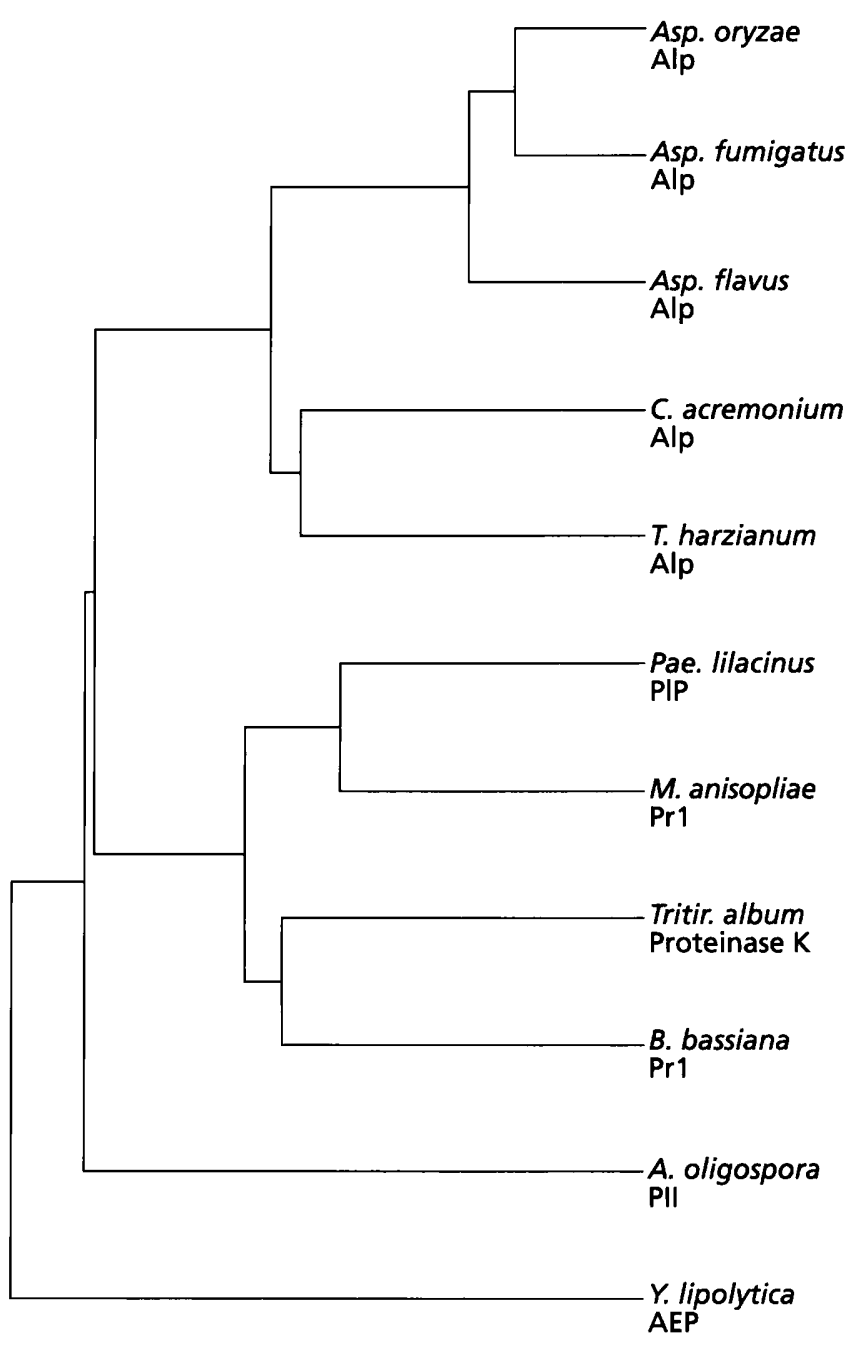

Fig. 3. Cluster analysis showing the similarity in the deduced amino acid sequence of 11 fungal serine proteases (GCG program PILEUP). The amino acid sequence of PII is compared with those of Alp from Asp. oryzae (Tatsumi et al., 1989), Alp from Asp. fumigatus (Jaton-Ogay et al., 1992), Alp from Asp. flavus (EMBL accession number L29262), Alp from C. acremonium (Isogai et al., 1991), Alp from $T$. harzianum (Geremia et al., 1993), PIP from Pae. lilacinus (Bonants et al., 1995), Pr1 from M. anisopliae (St Leger et al., 1992), Proteinase K from Tritir. album limber (Gunkel \& Gassen, 1989), Pr1 from B. bassiana (Joshi et al., 1995) and AEP from Y. lipolytica (Davidow et al., 1987).

interrupted by an intron of $61 \mathrm{bp}$ (position 512-573) which contains the highly conservative GT and AG nucleotide pairs in the $5^{\prime}$ and $3^{\prime}$ splice sites, respectively. Finally, the sequence ATAAA at position $1756,106 \mathrm{bp}$ downstream of the termination codon, may serve as a polyadenylation site (Gurr et al., 1987).

\section{Amino acid sequence}

The ORF translates to a polypeptide of 408 amino acid residues with a calculated molecular mass of $41949 \mathrm{Da}$, which is larger than the experimentally determined value of $35 \mathrm{kDa}$ using gel filtration (Tunlid et al., 1994), 
$\stackrel{\circ}{\circ}$
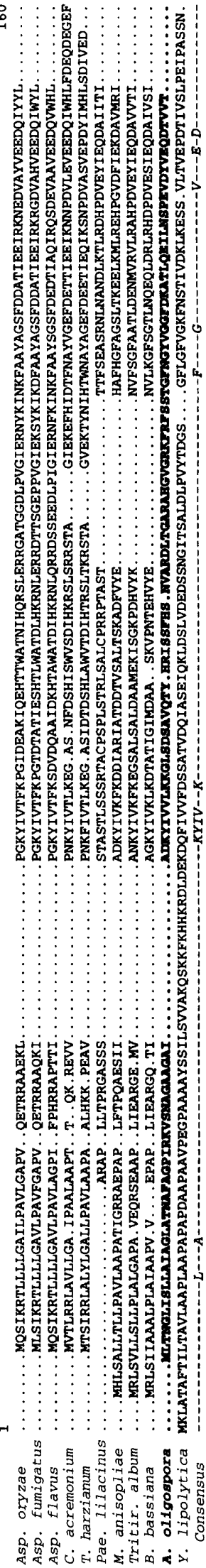

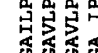

굽볍

部新

s.

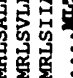
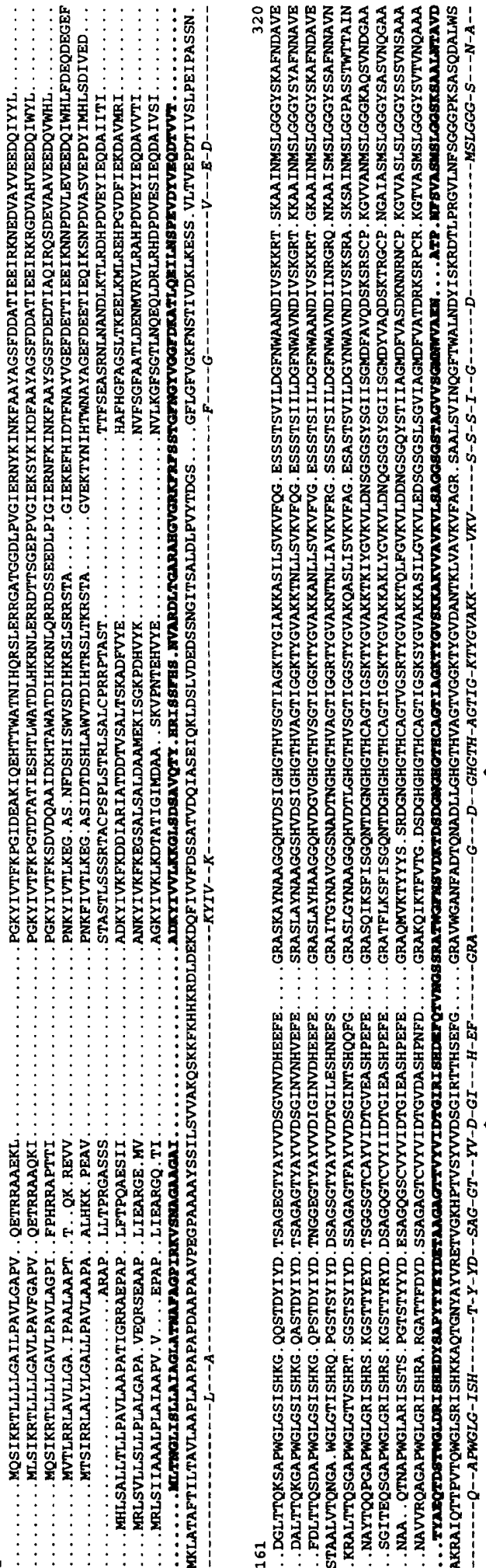

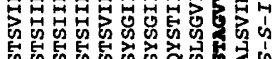

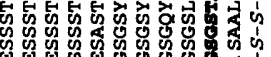
ws

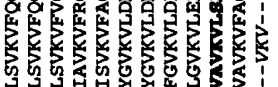

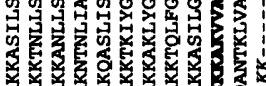

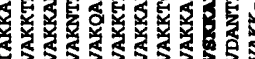
i
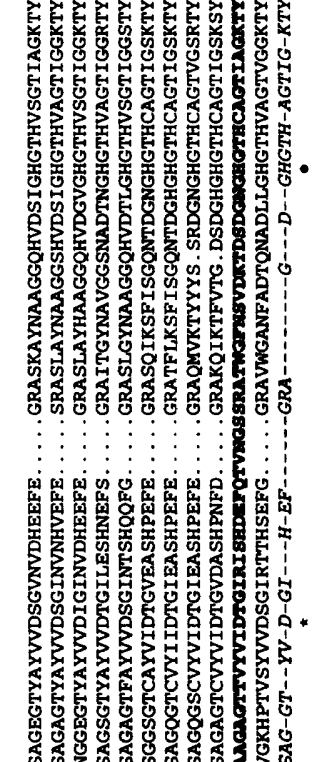

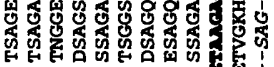

क्ष

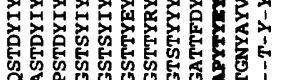

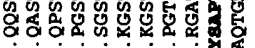

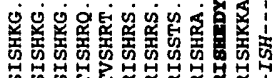

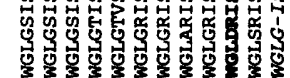

可

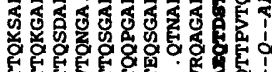

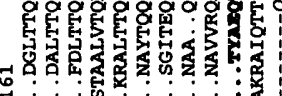

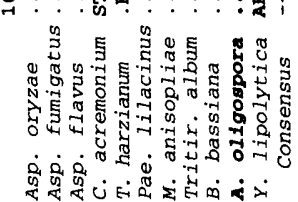

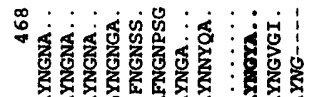

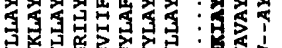

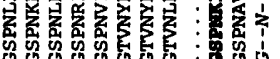

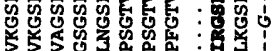

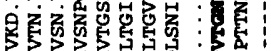

论

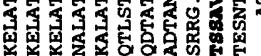

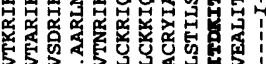

政

o

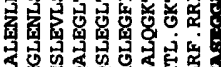

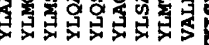

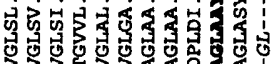

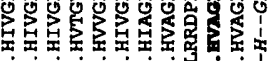

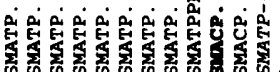

惫

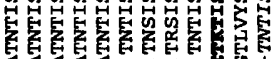

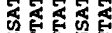

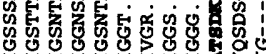

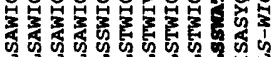

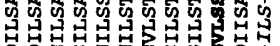

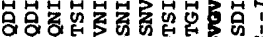

\%

证

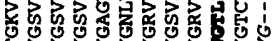

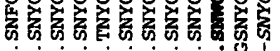

के

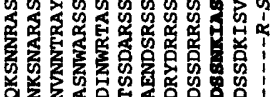

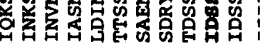

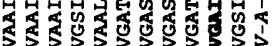

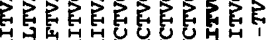

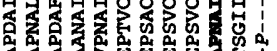

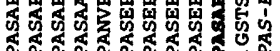

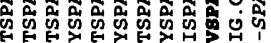

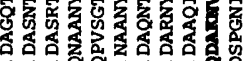

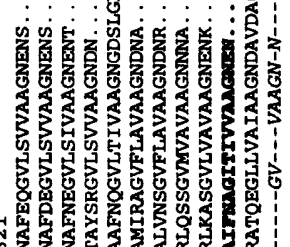

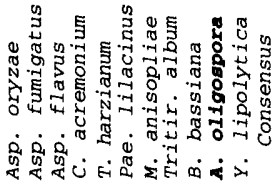

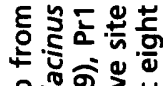

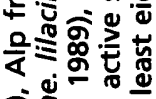

ลूँ

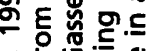

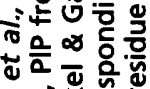

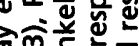

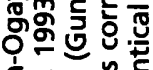

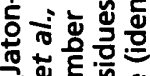

品

蛋

도을

方令定

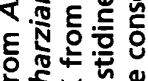

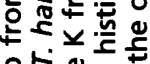

은

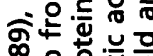

은은형늉응

产交高

-

हิ

苍志志高

的融

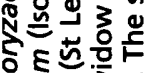

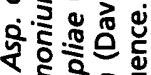

ह है웡

인 눙형

은노온

ㄷํㅇ ᅯ

药。ㅇㅇㅇ

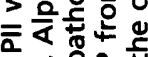

형융년

은 궈웡웡

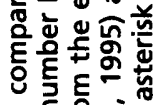

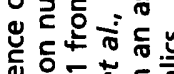

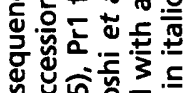

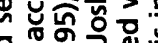

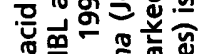

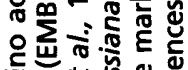

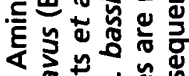

४

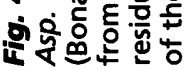




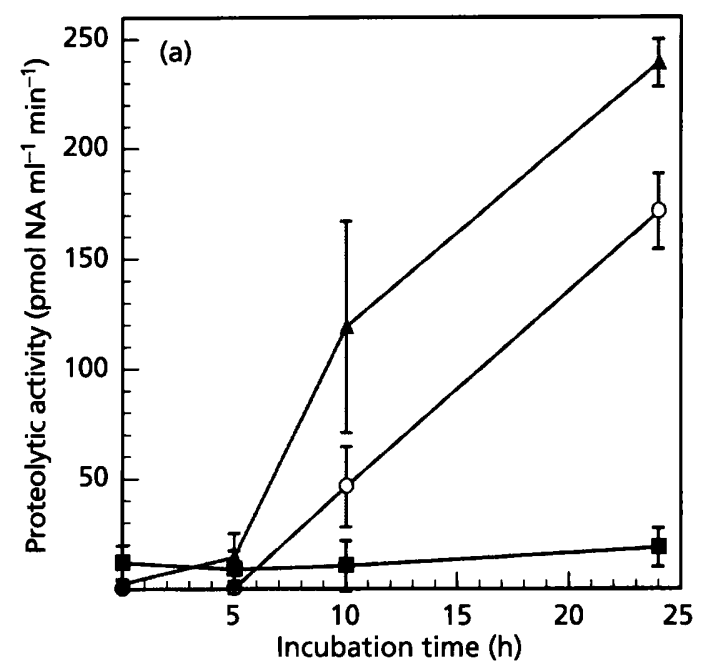

(b)

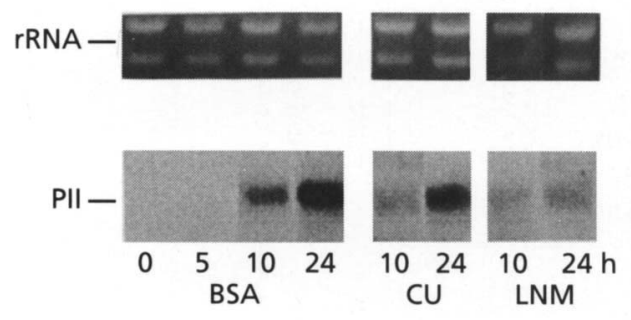

Fig. 5. Expression of the serine protease PII by A. oligospora incubated in LNM $+1 \mathrm{mg}^{2}$ albumin $\mathrm{ml}^{-1}$ (A), LNM $+1 \mathrm{mg}$ nematode cuticle $\mathrm{ml}^{-1}(O)$, or LNM only ( $\left.\boldsymbol{D}\right)$. Mycelia of $A$. oligospora were grown for $2 \mathrm{~d}$ in a nitrogen-limited medium before being transferred to LNM. Fragments of nematode cuticle were prepared from the nematode $P$. redivivus (Cox et al., 1981). (a) The proteolytic activity of extracellular PII (in the culture filtrates), as estimated by measuring the hydrolysis of the peptide substrate Bz-Phe-Val-Arg-NA. Bars indicate SD $(n=3)$. (b) Northern analysis of total RNA extracted from the mycelium. Ethidium-bromide-stained rRNA (top); filter hybridized with a ${ }^{32}$-labelled DNA fragment of PII (bottom).

indicating that the polypeptide encodes both the mature enzyme as well as a proregion and a signal peptide. The $\mathrm{N}$ terminal region of the deduced amino acid sequence resembles a typical eukaryotic signal peptide, with regard to the basic $\mathrm{N}$-terminal segment, followed by a stretch of uncharged, mostly hydrophobic residues. Based on the $(-3,-1)$ rule (von Heijne, 1983) and pairwise alignments to the subtilisin-related serine proteases Proteinase $\mathrm{K}$ from Tritiracbium album limber (Gunkel \& Gassen, 1989) and Pr1 from Metarbizium anisopliae (St Leger et al., 1992), we predict that the signal peptidase cleavage site is located between amino acid residues 16 and 17. Furthermore, based on alignments to Proteinase K, Pr1 and two alkaline proteinases (Alp) from Cephalosporium acremonium (Isogai et al., 1991) and Aspergillus oryzae (Tatsumi et al., 1989) we predict that the proregion of PII is cleaved between residues 120 and 121 (Fig. 1). The predicted molecular mass of the mature protease is $28528 \mathrm{Da}$.

Biochemical experiments have previously indicated that PII is glycosylated (Tunlid et al., 1994). The deduced primary sequence of the mature protease contains four potential $N$-linked glycosylation sites $\left(\mathrm{Asn}_{177}, \mathrm{Asn}_{247}\right.$, $\mathrm{Asn}_{251}$ and $A s n_{294}$ ), which follow the general rule of Asn-X-Thr/Ser, where $\mathrm{X}$ is any residue except perhaps aspartate, glutamic acid or proline (Mononen \& Karjalainen, 1984). The proregion lacks corresponding sites for glycosylation.

The codon usage in PII shows a very marked bias, as is common in highly expressed genes in filamentous fungi (Gurr et al., 1987). As a rule, whenever possible a $T$ or a $\mathrm{C}$ is preferred in the third position. Of all codons used in $P I I, 45 \%$ end with a $\mathrm{C}$ and $30 \%$ with a $\mathrm{T}, 12 \%$ with a $\mathrm{G}$ and $12 \%$ with an $\mathrm{A}$.

\section{Sequence comparison}

The data bank search showed that the nucleotide and deduced amino acid sequence of PII shared extensive similarities with both fungal and bacterial members of the subtilisin family of serine proteases. The sequence identity between PII and these proteases varied between 42 and $47 \%$ (pairwise alignments of the amino acids in the preproenzyme). The primary sequences of the fungal extracellular serine proteases were aligned using the program PILEUP, which by pairwise alignment creates a dendrogram showing the similarity between the sequences (Fig. 3). This analysis resulted in several clusters of proteases. However, the sequence of PII, as well as that of protease (AEP) isolated from the yeast Yarrowia lipolytica (Davidow et al., 1987), were outside these groups. This grouping of proteases was also found on inspection of the alignments by characteristic gaps and specific residues (Fig. 4). For example, the group of Proteinase K, Pr1 and the cuticledegrading protease (here designated PIP) from Paecilomyces lilacinus (Bonants et al., 1995) all contain four cysteine residues in conserved positions (residues 201, 296, 357 and 437 in Fig. 4) which are not present in the other proteases. On the other hand, a high degree of similarity between the sequences was found in regions containing the active site residues aspartic acid $\left(\mathrm{Asp}_{206}\right)$, histidine $\left(\mathrm{His}_{242}\right)$ and serine $\left(\mathrm{Ser}_{410}\right)$ (Fig. 4). The two blocks of side-chains that form the sides of the substrate-binding $S_{1}$ pocket in subtilisin occur in regions of high similarity and consist of $\operatorname{Ser}_{258} \mathrm{Leu}_{259} \mathrm{Gly}_{260}$ and $\mathrm{Ala}_{284} \mathrm{Ala}_{285} \mathrm{Gly}_{286}$ respectively, in PII. Furthermore, the highly conserved $\mathrm{Asn}_{287}$ (in PII) is important in subtilisin for stabilization of the reaction intermediate formed during proteolysis (Kraut, 1977).

To further investigate whether the similarity of sequences indicated in Figs 3 and 4 reflects phylogenetic relationships between the fungi, the serine protease sequences were also analysed by the programs available within PHYLIP version $3.5 \mathrm{c}$. The distant matrix methods (FITCH, KITCH and Neighbor-joining) resulted in a clustering of the proteases almost identical to that presented in Fig. 3 . A slightly different clustering of the proteases was obtained using the parsimony method (PROTPARS). As with the other methods, PII and AEP were placed at a distance from a group of proteases from $T$. album, $M$. anisopliae, Pae. lilacinus and Beauveria bassiana (Joshi et al., 
Table 2. Induction of PII by various proteins, nematode cuticle and polyamino acids

Mycelia of $A$. oligospora were grown for $2 \mathrm{~d}$ in nitrogen-limited medium before being transferred to LNM supplemented with various proteins, nematode cuticle or polyamino acids as inducing substrate. The level of PII was determined in the culture filtrates after $24 \mathrm{~h}$ incubation by measuring the hydrolysis of the peptide substrate $\mathrm{Bz}-\mathrm{Phe}-\mathrm{Val}-\mathrm{Arg}-\mathrm{NA}$. The values are expressed as percentages of the level of PII in the medium containing LNM + albumin (mean value $=120 \mathrm{pmol} \mathrm{NA} \mathrm{ml} \mathrm{min}^{-1}$, for three replicates, $\mathrm{SD}=5 \cdot 4$ ). Proteins and polyamino acids were added in concentrations of 1 and $0.5 \mathrm{mg} \mathrm{ml}^{-1}$, respectively.

\begin{tabular}{|lc|}
\hline Substrate & $\begin{array}{c}\text { Relative activity (\%) } \\
\text { [mean (SD)] }\end{array}$ \\
\hline LNM + albumin & $100 \cdot 0$ \\
LNM & $5 \cdot 55(2 \cdot 63)$ \\
LNM + soya peptone & $49 \cdot 7(6 \cdot 2)$ \\
LNM + collagen & $3 \cdot 88(1 \cdot 75)$ \\
LNM + gelatin & $21 \cdot 5(10 \cdot 9)$ \\
LNM + nematode cuticle* & $71 \cdot 6(7 \cdot 2)$ \\
LNM + polyglycin (5000-10000 Da) & $1 \cdot 22(0 \cdot 90)$ \\
LNM + poly-L-glutamic acid (600 Da) & $17 \cdot 8(5 \cdot 2)$ \\
LNM + poly-L-glutamic acid (2000-15000 Da) & $32 \cdot 6(9 \cdot 9)$ \\
LNM + poly-L-glutamic acid (15000-50000 Da) & $41 \cdot 5(18 \cdot 0)$ \\
LNM + poly-L-glutamic acid (50000-100000 Da) & $38 \cdot 9(5 \cdot 52)$ \\
LNM + poly-D-glutamic acid (2000-15000 Da) & $0 \cdot 95(0 \cdot 88)$ \\
\hline
\end{tabular}

* Fragments of cuticle were prepared from the nematode $P$. redivivus (Cox et al., 1981).

1995) and from one group formed by the proteases from Trichoderma barzianum (Geremia et al., 1993) and $C$. acremonium. However, the proteases from Aspergillus were not grouped together but found at different positions in the tree (data not shown).

\section{Induction of PII}

Induction of PII was tested in a series of growth experiments using nitrogen-limited cultures of $A$. oligospora, because other experiments have shown that the production and secretion of extracellular proteases in fungi can be affected by the presence of intracellular nitrogen pools (Cohen \& Drucker, 1977). To obtain nitrogen-starved cultures of $A$. oligospora, the fungus was grown for $2 \mathrm{~d}$ in LNM containing $10 \mathrm{~g}_{\text {glucose }} \mathrm{l}^{-1}$ and $0.2,0.02$ or $0.002 \mathrm{~g} \mathrm{NaNO}_{3} \mathrm{l}^{-1}$. The mycelium was then transferred into fresh LNM/glucose medium lacking a nitrogen source and the growth of the mycelium was examined after $2 \mathrm{~d}$ incubation. Some growth occurred in samples collected from the LNM/glucose medium containing 0.2 or $0.02 \mathrm{~g} \mathrm{NaNO}_{3} \mathrm{l}^{-1}$, but not in those recovered from the medium containing the lowest level of $\mathrm{NaNO}_{3}\left(0.002 \mathrm{~g} \mathrm{l}^{-1}\right)$ (data not shown).

When such a nitrogen-starved culture of $A$. oligospora was transferred to LNM containing BSA or purified cuticle fragments from the nematode $P$. redivivus as the sole source of carbon and nitrogen (at a concentration of $1 \mathrm{mg} \mathrm{ml}^{-1}$ ), the mycelium started to produce and secrete PII into the medium (Fig. 5a). Proteolytic activity of PII was also detected in the culture filtrates from mycelium incubated in LNM only, but this activity was significantly lower than in the medium containing the protein sources ( 5 to 20 -fold lower, depending on the incubation time and protein source). The stimulation of PII production was not paralleled by a corresponding increase in mycelial biomass [the dry weight of mycelium incubated in LNM for $24 \mathrm{~h}$ was $2.93 \mathrm{mg} \pm 0.32$ (mean $\pm \mathrm{sD}$ ) and in LNM + albumin, $3.05 \mathrm{mg} \pm 0 \cdot 28$. The effect of using a medium with a higher concentration of the inducing protein was evaluated by incubating the fungus in LNM containing $10 \mathrm{mg}$ albumin $\mathrm{ml}^{-1}$. After $24 \mathrm{~h}$ incubation, the dry weight of the mycelium incubated in this medium was about three times higher than that incubated in the medium containing $1 \mathrm{mg}$ albumin $\mathrm{ml}^{-1}$. However, after $24 \mathrm{~h}$ incubation, the activity of PII was 165 pmol NA $\mathrm{ml}^{-1} \mathrm{~min}^{-1}$ in the medium with $10 \mathrm{mg}$ albumin $\mathrm{ml}^{-1}$ compared to $237 \mathrm{pmol} \mathrm{NA} \mathrm{ml}^{-1} \mathrm{~min}^{-1}$ in the medium with $1 \mathrm{mg}$ albumin $\mathrm{ml}^{-1}$, which indicates that the higher concentration of albumin repressed the production of PII. Therefore, in the following experiments the inducing proteins or peptides were tested at a concentration of $1 \mathrm{mg} \mathrm{ml}^{-1}$ or lower.

By using the cloned PII gene as a probe, it was possible by Northern blotting to detect the PII mRNA in the mycelium incubated in LNM, LNM+albumin or LNM + cuticle after approximately $10 \mathrm{~h}$ incubation (Fig. $5 \mathrm{~b})$. The size of the PII mRNA was estimated by using commercially available RNA size markers to be approximately $1.5-1.6 \mathrm{~kb}$, which was within the range of the expected size of the PII transcript (cf. Fig. 1). The variations in the level of the PII mRNA followed approximately the changes in the activity of PII; it increased with time of incubation and it was significantly 
Table 3. Effects of primary and secondary nitrogen sources and glucose on the production of PII

Mycelia of $A$. oligospora were grown for $2 \mathrm{~d}$ in nitrogen-limited media before being transferred to LNM + albumin, and supplements of various nitrogen sources or glucose. The level of PII was determined in the culture filtrates after $24 \mathrm{~h}$ incubation by measuring the hydrolysis of the peptide substrate $\mathrm{Bz}-\mathrm{Phe}-\mathrm{Val}$ Arg-NA. The values are expressed as percentages of the level of PII in the medium containing LNM + albumin (mean value $=$ $75.7 \mathrm{pmol} \mathrm{NA} \mathrm{ml}{ }^{-1} \mathrm{~min}^{-1}$, for three replicates, $\mathrm{SD}=10 \cdot 40$ ). All supplements were added at $1 \mathrm{mg} \mathrm{ml}^{-1}$ except where indicated.

\begin{tabular}{|lc|}
\hline Supplement & $\begin{array}{c}\text { Relative activity (\%) } \\
\text { [mean (SD)] }\end{array}$ \\
\hline $\mathrm{NH}_{4} \mathrm{Cl}\left(10 \mathrm{mg} \mathrm{ml}^{-1}\right)$ & $3 \cdot 53(3 \cdot 19)$ \\
$\mathrm{NH}_{4} \mathrm{Cl}\left(1 \cdot 0 \mathrm{mg} \mathrm{m}^{-1}\right)$ & $17 \cdot 4(14 \cdot 6)$ \\
$\mathrm{NH}_{4} \mathrm{Cl}\left(0 \cdot 1 \mathrm{mg} \mathrm{m}^{-1}\right)$ & $109 \cdot 2(19 \cdot 2)$ \\
$\mathrm{NaNO}_{3}$ & $7 \cdot 8(2 \cdot 3)$ \\
Glutamine & $36 \cdot 8(15 \cdot 3)$ \\
Phenylalanine & $0 \cdot 27(0 \cdot 46)$ \\
Valine & $28 \cdot 9(3 \cdot 06)$ \\
Arginine & $34 \cdot 1(6 \cdot 1)$ \\
Tyrosine & $25 \cdot 7(3 \cdot 8)$ \\
Phenylalanyl-valine & $3 \cdot 98(3 \cdot 57)$ \\
Glucose & $50 \cdot 4(3 \cdot 57)$ \\
\hline
\end{tabular}

higher in the mycelium incubated in medium containing albumin or nematode cuticle compared to the mycelium incubated in LNM.

The production and secretion of PII were stimulated by several other insoluble and soluble protein substrates including polyamino acids (Table 2). Of the polyamino acids, the highest stimulation occurred in the medium containing poly-L-glutamic acid. A range of size classes of this peptide (from 600 to $100000 \mathrm{Da}$ ) induced the production of PII. In contrast, the production of PII was not stimulated by poly-D-glutamic acid or polyglycine. None of the used polyamino acids inhibited the growth of the mycelium of $A$. oligospora (data not shown).

\section{Regulation of PII}

Addition of $\mathrm{NH}_{4} \mathrm{Cl}$ at a concentration of $1.0 \mathrm{mg} \mathrm{ml}^{-1}$ or higher to LNM containing albumin repressed the production and secretion of PII (Table 3). No repression occurred at a concentration of $0.1 \mathrm{mg} \mathrm{NH}_{4} \mathrm{Cl} \mathrm{ml}^{-1}$. A number of other nitrogen compounds, including $\mathrm{NaNO}_{3}$ and several amino acids, also repressed the activity of PII. Most of the amino acids tested (Glu, Val, Arg or Tyr) repressed the production of PII less than $\mathrm{NH}_{4} \mathrm{Cl}$. One notable exception was Phe, which almost completely inhibited the activity of PII. A peptide containing Phe (Phe-Val), also strongly inhibited the activity of PII. The production of PII was also partly repressed by adding glucose to the LNM/albumin medium (Table 3).

In the absence of a protein inducer (albumin), supplements of an easily metabolized carbon source (glucose,

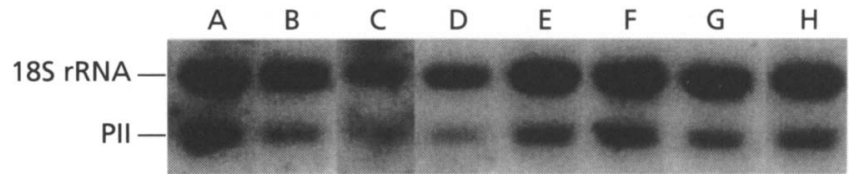

Fig. 6. Regulation of $P I I$ by various nitrogen sources and glucose. Nitrogen-starved mycelia of $A$. oligospora were incubated in LNM, albumin $\left(1 \mathrm{mg} \mathrm{ml}^{-1}\right)$ and supplements of various nitrogen sources or glucose $\left(1 \mathrm{mg} \mathrm{ml}^{-1}\right)$. After $24 \mathrm{~h}$ growth, the mycelium was harvested and total RNA was extracted and analysed by Northern blotting. The filters were hybridized with a ${ }^{32} \mathrm{P}$-labelled DNA fragment of PII (bottom) or with a DNA probe specific for 185 rRNA (top) (loading control). Lanes: A, no supplements (LNM + albumin); B, supplemented with $\mathrm{NH}_{4} \mathrm{Cl} ; \mathrm{C}, \mathrm{NaNO}_{3} ; \mathrm{D}$, glutamine; $\mathrm{E}$, phenylalanine; $\mathrm{F}$, valine; $G$, phenylalanyl-valine; $H$, glucose.

$\left.10 \mathrm{mg} \mathrm{ml}^{-1}\right)$ and nitrogen source $\left(\mathrm{NaNO}_{3}, 2 \mathrm{mg} \mathrm{ml}^{-1}\right)$ to LNM almost completely inhibited the production of PII (the proteolytic activity in the culture filtrates was $<1 \%$ of the level of PII in LNM/albumin) and it was not possible to detect the transcript of PII.

Northern blots of RNA extracted from the mycelium incubated in the media repressing the activity of PII showed that for several of the nitrogen sources $\left(\mathrm{NH}_{4} \mathrm{Cl}\right.$, $\mathrm{NaNO}_{3}, \mathrm{Gln}$ and $\mathrm{Val}$ ) as well as for glucose, a decreased activity of PII was paralleled by a decreased level of the PII transcript (Fig. 6). However, the strong inhibition of PII activity after adding Phe and Phe-Val was not correlated with a corresponding decrease in the level of the PII transcript. The level of this mRNA was similar to that observed in cultures incubated with Val.

\section{DISCUSSION}

The analysis of the sequence of $P I I$ isolated from $A$. oligospora indicated that the deduced primary structure of PII is similar to that of a number of other extracellular subtilisin-like serine proteases isolated from ascomycetes, including the cuticle-degrading serine proteases PIP from the nematophagous fungus Pae. lilacinus and Pr1 from the entomopathogen $M$. anisopliae. Several of these proteases formed groups of more closely related sequences, but the sequence of PII as well as that of the yeast protease AEP, were outside these groups. These relationships can be interpreted either in terms of phylogenetic distance between the species and/or as differences in the function of the enzymes. According to recent molecular phylogeny based on the analysis of rDNA, yeast (Hemiascomycetes) form an early branch within ascomycetes, separating them from filamentous ascomycetes (Taylor et al., 1994). Within the latter, rDNA gene sequences imply an early radiation of the apothecial ascomycetes (Discomycetes) from the cleistothecial (Plectomycetes) and perithecial (Pyrenomycetes) species (Gargas \& Taylor, 1995). Although there are no rDNA sequences of the deuteromycete $A$. oligospora available, the teleomorph of the closely related species Artbrobotrys superba was recently identified as the discomycete Orbilia fimicola (Pfister, 1994). The other 
ascomycetes from which the sequences of fungal serine proteases were analysed (Fig. 3) have either been placed among Plectomycetes (M. anisopliae, Pae. lilacinus, Aspergillus sp.) or Pyrenomycetes ( $T$. barzianum and $C$. acremonium) (Taylor et al., 1994; Radford, 1993; Curran et al., 1994; Tigano-Milani et al., 1995). Thus, the similarity of the sequences of the analysed serine protease can at least partly be explained by the proposed phylogeny of the species.

Several observations indicate that the differences in sequences between PII and the cuticle-degrading serine proteases PIP and Pr1 are also paralleled by differences in biochemical properties of the enzymes. PIP, Pr1, as well as Proteinase $\mathrm{K}$, are proteins with high $\mathrm{pI}$ values $(8 \cdot 9-10 \cdot 3)$ and they show a high level of activity with chymoelastase substrates containing aliphatic and/or aromatic amino acids (Ebeling et al., 1974; Bonants et al., 1995; St Leger et al., 1987). In contrast, PII has a low pI value (4.6) and preferably hydrolyses trypsin substrates like Bz-Phe-ValArg-NA (Tunlid et al., 1994). Extracellular serine proteases, except PIP, have also been purified and partly characterized from the nematode egg parasites Verticillium chlamydosporium (protease designated VCP1) and Verticillium suchlasporium (P32) (Segers et al., 1994; LopezLlorca, 1990). The complete sequences of VCP1 and P32 have not been reported, but it was recently demonstrated that they are serologically related to $\operatorname{Pr} 1$, and that the $\mathrm{N}$ terminus of VCP1 has a sequence related to that of $\operatorname{Pr} 1$ (Segers et al., 1995). Furthermore, VCP1 and P32 have high $\mathrm{pI}$ values and VCP1 has a substrate specificity that is similar to that of Pr1 (Lopez-Llorca, 1990; Segers et al., 1994). Whether the biochemical differences between PII and PIP, VCP1 and P32 are of importance for the ability of the enzymes to degrade components of the nematode cuticle and eggshells, respectively, are at present not known. In the case of Pr1, it has been suggested that the high $\mathrm{pI}$ value is of major importance for the hydrolytic activity and binding of the enzyme to fragments of insect cuticle (St Leger et al., 1992).

A comparison of serine protease sequences from fungi is complicated by the fact that several fungi are known to produce multiple extracellular serine proteases which might represent different functional groups of enzymes. For example, $M$. anisopliae produces a serine protease (Pr2) which has a similar pI value (4.4) and substrate specificity as PII (St Leger et al., 1987). Whether A. oligospora, or any other nematophagous fungi can produce both basic and acidic serine proteases with properties corresponding to $\operatorname{Pr} 1$ and Pr2 is not known. However, the Southern blot analysis indicated that there might exist other genes encoding subtilisin-like serine proteases in the genome of $A$. oligospora apart from PII. Future studies will show whether these putative genes which are clearly divergent from PII, encode extracellular serine proteases and are expressed during the degradation of the nematode cuticle.

The growth experiments indicated that the production and secretion of PII by $A$. oligospora are controlled by multiple regulatory circuits which include carbon and nitrogen metabolite repression as well as induction by several soluble and insoluble proteins, like fragments of nematode cuticle. Regulation of extracellular proteases by both induction and repression has been described for a number of filamentous fungi including Neurospora crassa (Drucker, 1972), the entomopathogens $M$. anisopliae and B. bassiana (St Leger et al., 1988; Paterson et al., 1993; Bidochka \& Khachatourians, 1988) and the human pathogen Candida albicans (Lerner \& Goldman, 1993). Most of these proteases can, like PII, be induced by a variety of protein substrates. However, the results from the growth experiments using polyamino acids indicate that there are some molecular features required of the peptide that can induce the production of PII. The peptides need to contain amino acids with side-chains, since polyglycine did not stimulate the production of PII, and they need to contain $\mathrm{L}$-amino acids, because the $\mathrm{L}$ - but not the D-isomer of polyglutamic acid stimulated the production of PII. The level of stimulation was also affected by the size of the inducing peptide. It was possible to induce the expression of PII using small peptides of $\mathrm{L}$ glutamic acid $(600 \mathrm{Da}$, corresponding to about 4-5 residues), but the production was further stimulated in media containing higher molecular mass fractions of this polyamino acid. These results differ from those obtained in similar experiments studying the induction of an extracellular aspartyl protease in Ca. albicans (Lerner \& Goldman, 1993). This protease can be induced by a number of different soluble and insoluble protein substrates, but in contrast to PII, it can be induced by Disomers of polyamino acids (e.g. poly-D-glutamic acid) and only by peptides having a size larger than about 8 residues. Thus the results from our experiments indicate that PII is induced by a different mechanism than that suggested for the Candida peptide permease (Milewski et al., 1988), probably involving the uptake of small peptides into the cell.

The low levels of PII, produced when the mycelium of $A$. oligospora is starved of both carbon and nitrogen, are probably important in the nutrient-poor soil environment for regulating the production of PII during the interaction with nematodes. A basal activity of PII would allow the transformation of the insoluble cuticle to a soluble inducer that can be transported into the cell and further stimulate the expression of the PII gene. Such a mechanism has so far not been demonstrated for the induction of fungal proteases, but it has been indicated for the induction of cellulolytic enzymes in the filamentous fungi Trichoderma reesei (El-Gogary et al., 1989). Furthermore, the proteolytic activity of PII was almost completely inhibited by the peptide Phe-Val, as well as Phe, but not to the same extent by other tested amino acids including Val, Gln, Arg and Tyr. Notably, peptides containing a high proportion of non-polar and aromatic amino acids (like Phe-Val) are present in the exudate from the nematode $P$. redivivus, and such peptides, as well as the amino acids $P$ he and Val favour the formation of infection structures (traps) of $A$. oligospora, particularly in media with low levels of nitrogen and carbon (Nordbring-Hertz, 1973, 1977; Nordbring-Hertz \& Brinck, 1974). The biological function and mechanistic basis for the differences in the 
repression of PII by the tested amino acids are not known, but the results indicate that the activity of PII can be regulated by products released from the host and by compounds known to be involved in the differentiation of the infection structures of $A$. oligospora. Furthermore, since the levels of the PII mRNA were similar in the mycelium incubated with these amino acids, the regulation probably occurs through mechanisms acting at both the transcriptional and post-transcriptional (e.g. translational control, processing of pre-proenzyme) levels.

The decreased level of the PII mRNA in the presence of ammonia in the medium indicates that the expression of PII could be under the control of a complex regulatory circuit controlled by the product of a global regulatory gene (are $A$ or nit-2) as in Aspergillus and Neurospora (Marzluf, 1993). Analysis of the sequence upstream from the identified ATG start codon of PII present in the pUBH clone revealed the presence of nine putative GATA core elements (in either orientation). Six of these (with the $5^{\prime}$ end at positions $-810,-808,-789,-505$ and -496 in relation to the ATG start codon) have a spacing and orientation that fulfill the requirements of a strong NIT2 binding site in $N$. crassa (Chiang \& Marzluf, 1994).

Isolation of $P I I$ and studies on its regulation are important steps for analysing the role of cuticle-degrading proteases in the pathogenicity of $A$. oligospora. A long-term goal is to use such enzymes to develop new methods to control plant- and animal- parasitic nematodes. One possibility is to mass-produce the enzyme by overexpression of the corresponding gene in a heterologous system and directly apply the enzyme to the environment of the parasites. Alternatively, genes encoding cuticle-degrading enzymes can be transferred into other organisms including hosts of the parasites or micro-organisms that are common in the habitat of the parasites. Finally, by using genetic engineering, it should be possible to alter the structure of cuticle-degrading proteases and thereby obtain enzymes with modified activities and properties. To this end, it will be important to obtain further information on how these enzymes digest the nematode cuticle.

\section{ACKNOWLEDGEMENTS}

This study was supported by grants from the Banks of Sweden Tercentary Foundation, the Swedish Council for Forestry and Agricultural Research, Carl Tryggers Stiftelse and Magnus Bergvalls Stiftelse. We thank Dr Lars-Olof Hedén and Professor John W. Taylor for stimulating discussions.

\section{REFERENCES}

Bidochka, M. J. \& Khachatourians, G. G. (1988). Regulation of extracellular protease in the entomopathogenic fungus Beawveria bassiana. Exp Mycol 12, 161-168.

Bonants, P. J. M., Fitters, P. F. L., Thijs, H., Den-Belder, E., Waalwijk, C. \& Henfling, J. W. D. M. (1995). A basic serine protease from Paecilomyces lilacinus with biological activity against Meloidogyne bapla eggs. Microbiology 141, 775-784.

Chiang, T.-Y. \& Marzluf, G. A. (1994). DNA recognition by the NIT2 nitrogen regulatory protein: importance of the number, spacing and orientation of GATA core elements and their flanking sequences upon NIT2 binding. Biochemistry 33, 576-582.

Chomczynski, P. \& Sacchi, N. (1987). Single-step method of RNA isolation by acid guanidinium thiocyanate-phenol-chloroform extraction. Anal Biochem 162, 156-159.

Cohen, B. L. \& Drucker, H. (1977). Regulation of exocellular protease in Neurospora crassa: induction and repression under conditions of nitrogen starvation. Arch Biochem Biophys 182, 601-613.

Corden, J., Wasylyk, B., Buchwalder, A., Sassone-Corsi, P., Kedinger, C. \& Chambon, P. (1980). Expression of cloned genes in new environment. Promoter sequences of eukaryotic proteincoding genes. Science 209, 1406-1414.

Cox, G. N., Kusch, M. \& Edgar, R. S. (1981). Cuticle of Caenorhabditis elegans: its isolation and partial characterization. J Cell Biol 90, 7-17.

Curran, J., Driver, F., Ballard, J. W. O. \& Milner, R. J. (1994). Phylogeny of Metarbizium: analysis of ribosomal DNA sequence data. Mycol Res 98, 547-552.

Davidow, L. S., O'Donnell, M. M., Kaczmarek, F. S., Pereira, D. A., Dezeeuw, J. R. \& Franke, A. E. (1987). Cloning and sequencing of the alkaline extracellular protease gene of Yarrowia lipolytica. J Bacteriol 169, 4621-4629.

Drucker, H. (1972). Regulation of exocellular proteases in Neurospora crassa: induction and repression of enzyme synthesis. $J$ Bact 110, 1041-1049.

Ebeling, W., Hennrich, N., Klockow, M., Metz, H., Orth, H. D. \& Lang, H. (1974). Proteinase $K$ from Tritirachium album limber. Eur $J$ Biochem 47, 91-97.

El-Gogary, S., Leite, A., Crivellaro, O., Eveleigh, D. E. \& El-Dorry, H. (1989). Mechanism by which cellulose triggers cellobiohydrolase I gene expression in Trichoderma reesei. Proc Natl Acad Sci US A 86, 6138-6141.

Felsenstein, J. (1989). PHYLIP - Phylogeny Inference Package (version 3.2). Cladistics 5, 164-166.

Gargas, A. \& Taylor, J. W. (1995). Phylogeny of discomycetes and early radiations of the apothecial ascomycotina inferred from SSU rDNA sequence data. Exp Mycol 19, 7-15.

Geremia, R. A., Goldman, G. A., Jacobs, D., Vila, S. B., Ardiles, W., Van Montagu, M. M. \& Herrera-Estrella, A. (1993). Molecular characterization of the proteinase-encoding gene Prb1 related to mycoparasitism by Trichoderma harzianum. Mol Microbiol 8, 603-613.

Grønvold, J., Wolstrup, J., Nansen, P. \& Henriksen, S. A. (1993). Nematode-trapping fungi against parasitic cattle nematodes. Parasitol Today 9, 137-140.

Gunkel, F. A. \& Gassen, H. G. (1989). Proteinase K from Tritirachium album limber. Characterization of the chromosomal gene and expression of the cDNA in Escherichia coli. Eur J Biochem 179, 184-194.

Gurr, S. J., Unkles, S. E. \& Kinghorn, J. R. (1987). The structure and organization of nuclear genes of filamentous fungi. In Gene Structure in Eukaryotic Microbes. Special Publication of the Society for General Microbiology, Vol. 22, pp. 93-139. Edited by J. R. Kinghorn. Oxford: IRL Press.

von Heijne, G. (1983). Patterns of amino acids near signal-sequence cleavage sites. Eur J Biochem 133, 17-21.

Isogai, T., Fukagawa, T. I. M., Kohsaka, H. K. M., Aoki, H. \& Imanaka, H. (1991). Cloning and nucleotide sequences of the complementary and genomic DNAs for the alkaline protease from Cephalosporium acremonium. Agric Biol Cbem 55, 471- 477.

Jaton-Ogay, K., Suter, M., Crameri, R., Falchetto, R., Fatih, A. \& Monod, M. (1992). Nucleotide sequence of a genomic and a cDNA 
clone encoding an extracellular alkaline protease of Aspergillus fumigatus. FEMS Microbiol Lett 92, 163-168.

Joshi, L., St Leger, R. J. \& Bidochka, M. J. (1995). Cloning of a cuticle-degrading protease from the entomopathogenic fungus Beauveria bassiana. FEMS Microbiol Lett 125, 211-218.

Kerry, B. (1990). An assessment of progress toward microbial control of plant-parasitic nematodes. J Nematol 22, 621-631.

Kraut, J. (1977). Serine proteases structure and mechanism of catalysis. Annu Rev Biochem 46, 331-358.

Lerner, C. G. \& Goldman, R. C. (1993). Stimuli that induce production of Candida albicans extracellular aspartyl proteinase. J Gen Microbiol 139, 1643-1651.

Lipman, D. J. \& Pearson, W. R. (1985). Rapid and sensitive protein similarity searches. Science 227, 1435-1441.

Lopez-Llorca, L. V. (1990). Purification and properties of extracellular proteases produced by the nematophagous fungus $V$ erticillium suchlasporium. Can J Microbiol 36, 530-537.

Marzluf, G. A. (1993). Regulation of sulfur and nitrogen metabolism in filamentous fungi. Annu Rev Microbiol 47, 31-55.

Milewski, S., Andruszkiewicz, R. \& Borowski, E. (1988). Substrate specificity of peptide permeases in Candida albicans. FEMS Microbiol Lett 50, 73-78.

Mononen, I. \& Karjalainen, E. (1984). Structural comparison of protein sequences around potential $N$-glycosylation sites. Biochim Biopbys Acta 788, 364-367.

Nordbring-Hertz, B. (1973). Peptide-induced morphogenesis in the nematode-trapping fungus Artbrobotrys oligospora. Physiol Plant 29, 223-233.

Nordbring-Hertz, B. (1977). Nematode induced morphogenesis in the predacious fungus Arthrobotrys oligospora. Nematologica 23, 443-451.

Nordbring-Hertz, B. \& Brinck, C. (1974). Qualitative characterization of some peptides inducing morphogenesis in the nematode trapping fungus Artbrobotrys oligospora. Physiol Plant 31, 59-63.

Paterson, I. C., Charnley, A. K., Cooper, R. M. \& Clarkson, J. M. (1993). Regulation of production of a trypsin-like protease by the insect pathogenic fungus Metarbizium anisopliae. FEMS Microbiol Lett 109, 323-328.

Pfister, D. H. (1994). Orbilia fimicola, a nematophagous discomycete and its Artbrobotrys anamorph. Mycologica 86, 451-453.

Radford, A. (1993). A fungal phylogeny based upon orotidine 5'monophosphate decarboxylase. J Mol Evol 36, 389-395.

Riviere, L. R., Flemming, M., Elicone, C. \& Tempest, P. (1991). Study and applications of the effects of detergents and chaotropes on enzymatic protolysis. In Techniques in Protein Chemistry, Vol. 11, pp. 171-179. Edited by J. J. Villafranca. London: Academic Press.

Sambrook, S., Fritsch, E. F. \& Maniatis, T. (1989). Molecular Cloning : A Laboratory Manual. Cold Spring Harbor, NY: Cold Spring Harbor Laboratory.

Sanger, F., Nicklen, S. \& Coulson, A. R. (1977). DNA sequencing with chain-terminating inhibitors. Proc Natl Acad Sci USA 89, 7174-7178.

Segers, R., Butt, T. M., Kerry, B. R. \& Peberdy, J. F. (1994). The nematophagous fungus Verticillium chlamydosporium Goddard produces a chymoelastase-like protease which hydrolyses host nematode proteins in situ. Microbiology 140, 2715-2723.

Segers, R., Butt, T. M., Keen, J. N., Kerry, B. R. \& Peberdy, J. F. (1995). The subtilisins of the invertebrate mycopathogens Verticillium cblamydosporium and Metarbizium anisopliae are serologically and functionally related. FEMS Microbiol Lett 126, 227-231.

St Leger, R. J., Charnley, A. K. \& Cooper, R. M. (1987). Characterization of cuticle-degrading proteases produced by the entomopathogen Metarbizium anisopliae. Arch Biochem Biopbys 253, 221-232.

St Leger, R. J., Durrands, P. K., Cooper, R. M. \& Charnley, A. K. (1988). Regulation of production of proteolytic enzymes by the entomopathogenic fungus Metarbizium anisopliae. Arcb Microbiol 150, 413-416.

St Leger, R. J., Frank, D. C., Roberts, D. W. \& Staples, R. C. (1992). Molecular cloning and regulatory analysis of the cuticle-degrading protease structural gene from the entomopathogenic fungus Metarbizium anisopliae. Eur J Biochem 204, 991-1001.

Tatsumi, H., Ogawa, Y., Murakami, S., Ishida, Y., Murakami, K., Masaki, A., Kawabe, H., Arimura, E. \& Motai, H. (1989). A full length cDNA clone for the alkaline protease from Aspergillus oryzae: structural analysis and expression in Saccharomyces cerevisiae. Mol Gen Genet 219, 33-38.

Taylor, J. W., Swann, E. C. \& Berbee, M. L. (1994). Molecular evolution of ascomycete fungi: phylogeny and conflict. In Ascomycete Systematics: Problems and Perspectives in the Nineties, pp. 201-212. Edited by D. L. Hawksworth. New York: Plenum Press.

Tigano-Milani, M. S., Samson, R. A., Martins, I. \& Sobral, B. W. S. (1995). DNA markers for differentiating isolates of Paecilomyces lilacinus. Microbiology 141, 239-245.

Tunlid, A. \& Jansson, S. (1991). Proteases and their involvement in the infection and immobilization of nematodes by the nematophagous fungus Artbrobotrys oligospora. Appl Environ Microbiol 57, 2868-2872.

Tunlid, A., Rosén, S., Ek, B. \& Rask, R. (1994). Purification and characterization of an extracellular serine protease from the nematode-trapping fungus Arthrobotrys oligospora. Microbiology 140, 1687-1695.

Wostemeyer, J. (1985). Strain-dependent variation in ribosomal DNA arrangement in Absidia glauca. Eur J Biochem 146, 443-448.

Yakura, K., Kato, A. \& Tanifuji, S. (1984). Length heterogeneity of the large spacer of Vicia faba rDNA is due to the differing number of a $325 \mathrm{bp}$ repetitive sequence elements. Mol Gen Genet 193, $400-405$.

Received 12 December 1995; revised 9 February 1996; accepted 21 February 1996. 